\title{
The effect of varying the quality of dietary protein and energy on food intake and growth in the Zucker rat
}

\author{
BY J. D. RADCLIFFE* AND A. J. F. WEBSTER† \\ The Rowett Research Institute, Bucksburn, Aberdeen AB2 $9 S B$
}

$$
\text { (Received } 26 \text { April } 1978 \text { - Accepted 31 May 1978) }
$$

I. Food intake and rates of protein, lipid and energy deposition were measured for lean and obese (fatty) Zucker rats offered to appetite from $34 \mathrm{~d}$ of age to slaughter at $66 \mathrm{~d}$ of age, one of sixteen semi-synthetic diets. Measurements were also made of the digestibility of dietary protein and the metabolizability of dietary energy. Total carcasses were analysed for protein and lipid, and body energy was calculated thereby. Changes in body constituents were calculated by the comparative-slaughter technique.

2. In Expt I, four rats of each phenotype and sex were offered one of four diets, each of which contained either 150 or $300 \mathrm{~g}$ casein ( $150 \mathrm{C}$ and $300 \mathrm{C}$ respectively)/ $\mathrm{kg}$ and either 150 or $300 \mathrm{~g}$ cellulose (I 50 CELL and $300 \mathrm{CELL}$ respectively) $/ \mathrm{kg}$ (diets $150 \mathrm{C} / 150 \mathrm{CELL}, 150 \mathrm{C} / 300 \mathrm{CELL}, 300 \mathrm{C} / \mathrm{I} 50 \mathrm{CELL}$ and $300 \mathrm{C} / 300 \mathrm{CELL}$. As expected, males ate more and had higher rates of protein deposition than female animals of the same phenotype on all diets. These sex differences were greater for the lean phenotype. The results for animals in this experiment are presented with, and discussed in relation to, those obtained previously for animals of both sexes fed on cellulose-free diets having these two levels of casein.

3. In Expt 2, four female animals of each phenotype were fed one of twelve semi-synthetic diets, each of which contained casein, gluten or zein at one of the following levels (g crude protein (nitrogen $\times 6 \cdot 25$ ) $/ \mathrm{kg}$ diet): 93, 132, 267 or 627 . On all diets containing zein both fatty and lean rats had similar, low food intakes and failed to grow. Fatty rats fed on diets containing casein or gluten had higher rates of food intake, weight gain, lipid and energy deposition than lean sats, but similar rates of protein deposition. Rats fed on diets having the two lower levels of casein ate more and grew better than animals of the same phenotype fed on the two corresponding diets containing gluten but at higher protein levels differences in food intake and growth attributable to differences in protein quality disappeared and furthermore, the rate of protein deposition became similar and maximal for both phenotypes.

4. The results from both experiments are discussed in relation to previous work on appetite control in the Zucker rat. It appears that fatty and lean rats eat during growth to attain the maximal rate of protein deposition of which they are capable. The rate of lipid deposition would appear to be of no importance in the food intake regulation of animals depositing protein maximally.

5. Rats given diets that fail to support maximal rates of protein deposition appear to regulate their intake of digestible energy rather than that of digestible protein. They do not overeat protein-deficient diets in order to acquire sufficient protein for maximal growth although the factors that induce satiety in these animals are unk nown.

In previous work, congenitally-obese (fatty) and lean Zucker rats of both sexes were given free access during growth to a range of diets whose protein content was varied by altering the proportion of casein (Radcliffe \& Webster, 1976, 1978). This work showed that the casein content of the diet had marked effects on food intake and rates of protein and lipid deposition during growth. When the protein content of the diet was adequate $(300 \mathrm{~g}$ casein $/ \mathrm{kg}$ ) rats were able to express their full physiological potential for protein deposition during growth and in these circumstances food intake for each sex and phenotype was intimately linked to this maximal rate of protein deposition, which was the same for females of both phenotypes, intermediate for fatty males and highest for lean males (Radcliffe \& Webster, 1978). The rate of lipid deposition appeared to have little or no bearing on food intake.

* Present address: The Laboratory of Pathophysiology, The National Cancer Institute, National Institute of Health, Bethesda, Maryland 20014, USA.

$\dagger$ Present address (for correspondence): Department of Animal Husbandry, University of Bristol, Langford House, Langford, Bristol BS 87 DU. 
Diets low in protein depressed food intake and growth rates. Again, both phenotypes responded in an essentially similar way to low-protein diets despite their phenotypic differences in total food intake and body composition when given normal diets. This reinforced the suggestion that hyperphagia in the fatty Zucker rat was a normal appetite response to an error of metabolism during growth, and hinted that further studies might clarify the factors that cause normal rats to limit their intake of imbalanced diets.

Meyer (1958) showed that substitution of cellulose for sucrose in a low-protein diet for rats increased total food intake and the rate of protein deposition. He concluded that rats given diets low in protein restrict food intake because they are unable to dispose of a relative excess of energy as heat or into lipid stores. Later, Meyer \& Hargus (1959) showed that if heat production was increased by cold or exercise, rats fed on low-protein diets ate more and grew faster. Variation in the quality of dietary protein is also known to influence food intake and growth in normal rats (Harper, Benevenga \& Wohlheuter, 1970). The cause of the restricted intake of rats given diets imbalanced with respect to amino acids is thought to be the need to maintain plasma amino acid homoeostasis, i.e. to prevent the level of the growthlimiting amino acid from becoming too low or the level of the non-limiting amino acids from becoming too high (Leung \& Rogers, 1969; Sanahuja \& Harper, 1973).

This paper describes two experiments. In the first the quality of the energy content of the diet was varied by substituting cellulose for sucrose in diets having casein contents of I50 and $300 \mathrm{~g} / \mathrm{kg}$ diet ( $150 \mathrm{C}$ and $300 \mathrm{C}$ respectively) (see Radcliffe \& Webster, I976). In the second experiment the quality of the dietary protein was varied by substituting gluten or zein for casein on an isonitrogenous basis. The diets also had low levels of lipid (approximately $20 \mathrm{~g}$ lipid $/ \mathrm{kg}$ ) and were compared with previous experiments in which all diets contained $200 \mathrm{~g}$ lipid/kg (Radcliffe \& Webster, I976, 1978).

These two experiments were designed to explore further the effects of dietary composition on growth in the Zucker rat and the fundamental process by which all rats regulate their intake of diets which are not of the right quality to support maximal growth.

\section{EXPERIMENTAL}

\section{Animals}

Sixty-four female and sixteen male rats of each phenotype of Zucker rat (see Zucker \& Zucker, 196I) were used. Rats were taken at $24 \mathrm{~d}$ of age from a breeding colony maintained under conditions of minimal disease at the Rowett Research Institute. Families of rats in the breeding colony were given a commercial, pelleted diet (Oxoid, H. C. Styles (Bewdley) Ltd, Bewdley, Worcs.). Weaned rats were then kept in minimal disease conditions in a room at an air temperature of $20^{\circ}$ with a $\mathrm{I} 2 \mathrm{~h}\left(09^{\circ} 00\right.$ hours - $2 \mathrm{I} \cdot 00$ hours) light-dark cycle. They were fed on Oxoid until 34 days of age, after which they received one of sixteen semi-synthetic diets.

In Expt I four animals of each sex and phenotype were given one of four diets (for details, see Table I) and in Expt 2 four female animals of each phenotype were given one of twelve diets.

In both experiments the animals were killed at $66 \mathrm{~d}$ of age. Any uneaten and spilled food was weighed daily to give a daily record of food intake.

\section{Diets}

In Expt I, I 50 and $300 \mathrm{~g}$ cellulose (I $50 \mathrm{CELL}$ and $300 \mathrm{CELL}$ respectively) were used to replace an equal weight of sucrose in diets $150 \mathrm{C}$ or $300 \mathrm{C}$ (see Radcliffe \& Webster, 1976). The cellulose powder was 'Whatmanchromedia' (W. \& R. Balston Ltd, England). Details of the analysis of the four resultant diets containing cellulose (diets $150 \mathrm{C} / \mathrm{I} 50 \mathrm{CELL}, \mathrm{I} 50 \mathrm{C} / 300$ 
Table I. Expt I. Composition of four diets containing $\mathrm{I} 50$ or $300 \mathrm{~g}$ cellulose (I 50 CELL and 300 CELL respectively) and $\mathrm{I} 50$ or $300 \mathrm{~g}$ casein $/ \mathrm{kg}$ ( $\mathrm{I} 50 \mathrm{C}$ and $300 \mathrm{C}$ respectively) together with that of diets containing I 50 or $300 \mathrm{~g}$ casein $/ \mathrm{kg}$ but no cellulose

$\begin{array}{lccc}\text { Diet } & \begin{array}{c}\text { Crude protein } \dagger \\ (\mathrm{g} / \mathrm{kg})\end{array} & \begin{array}{c}\text { Lipid } \\ (\mathrm{g} / \mathrm{kg})\end{array} & \begin{array}{c}\text { Gross energy } \\ (\mathrm{MJ} / \mathrm{kg})\end{array} \\ \text { 150 C/I50 CELL } & 135 & 195 & 20 \cdot 4 \\ 150 \mathrm{C} / 300 \mathrm{CELL} & 138 & 195 & 20 \cdot 2 \\ 300 \mathrm{C} / \mathrm{I} 50 \mathrm{CELL} & 272 & 207 & 21 \cdot 3 \\ 300 \mathrm{C} / 300 \mathrm{CELL} & 276 & 204 & 21 \cdot 0 \\ 150 \mathrm{C} \ddagger & 135 & 197 & 20 \cdot 5 \\ 300 \mathrm{C} \ddagger & 269 & 202 & 21 \cdot 3 \\ & & & \\ & & \text { Nitrogen } \times 6 \cdot 25 . & \\ & \ddagger \text { Radcliffe \& Webster }(1976) .\end{array}$

CELL, $300 \mathrm{C} / \mathrm{I} 50 \mathrm{CELL}, 300 \mathrm{C} / 300 \mathrm{CELL}$ ) are given in Table I together with those of the original diets of Radcliffe \& Webster (1976) which contained 150 or 300 C but o CELL.

In Expt 2, four low-fat (LF) diets were made for each of the proteins, casein, gluten and zein (technical grade, Sigma, London). Diets containing gluten and zein were compounded so as to be approximately isonitrogenous with corresponding $\mathrm{C}$ diets. Diets containing casein had $100,150,300$ or $700 \mathrm{~g}$ casein $/ \mathrm{kg}$ diet which provided respectively $93,132,267$, or $627 \mathrm{~g}$ crude protein $(\mathrm{N} \times 6.25) / \mathrm{kg}$ diet. These diets were called $\mathrm{LF} / \mathrm{I} 00 \mathrm{C}, \mathrm{LF} / \mathrm{I} 50 \mathrm{C}$, LF/ $300 \mathrm{C}$ and LF/700 C respectively. Four gluten diets, LF/I00 G, LF/I50 G, LF/300 G and $\mathrm{LF} / 700 \mathrm{G}$, and four zein diets, $\mathrm{LF} / 100 \mathrm{Z}, \mathrm{LF} / 150 \mathrm{Z}, \mathrm{LF} / 300 \mathrm{Z}$ and LF/700 Z, were made up so as to be isonitrogenous to the corresponding casein diets. Thus all diets contained $93,132,267$, or $627 \mathrm{~g}$ crude protein. The nominal values $100,150,300$ and 700 have been used for convenience and to ensure consistency with expressions used in our earlier work (Radcliffe \& Webster, 1976, 1978).

All these diets contained, in addition, $(\mathrm{g} / \mathrm{kg}$ ): glycerol $\mathrm{I} 50$, sunflower-seed oil 20 , mineral mix, 37, trace element mix 2, vitamin mix 50. The composition of the mineral, vitamin and trace element mixes has been given previously (Radcliffe \& Webster, 1976). All diets were made to I $\mathrm{kg}$ with sucrose. The results of the analysis of the twelve diets used in Expt 2 are given in Table 2 which shows that corresponding diets were approximately isonitrogenous, although there was a small increase in energy content with increasing substitution of protein for sucrose.

\section{Trials and analysis}

Collections of urine and faeces were made from rats using individual, stainless-steel metabolism cages (North Kent Plastic Cages Ltd, Dartford, Kent). Each collection period lasted 4 days. The first was done when the animals were $40 \mathrm{~d}$ of age, the second one $\mathrm{I} 6 \mathrm{~d}$ later. The conduct of these trials has been described previously (Radcliffe \& Webster, 1976). Rats were killed by carbon dioxide inhalation. Samples of diets, urine, faeces and carcasses were treated as before (Radcliffe \& Webster, 1976). All analyses were done in triplicate. The gross energy of faeces, urine and diets was determined by adiabatic bomb calorimetry, the $\mathrm{N}$ content of faeces, carcasses and diets by the macro-Kjeldahl method (Davidson, Mathieson $\&$ Boyne, 1970) and the lipid content of carcasses and diets by the method of Atkinson, Fowler, Garton \& Lough (1972). All results were subjected to the analysis of variance.

Increases in body protein and lipid were calculated using the comparative-slaughter procedure. Estimates of the body protein and lipid at $34 \mathrm{~d}$ of age were based on analyses done previously for animals of both sexes and phenotypes at this age (Radcliffe \& Webster, 1976, 1978). Body energy was calculated by adding together the estimated energy content of the body lipid and protein. The heats of combustion of these were taken to be 38 and 
Table 2. Expt 2. Composition of twelve low-fat $(L F)$ diets in which protein was provided by the inclusion of casein ( $100 C, 150 C, 300 C$ and $700 C$ respectively) gluten (100 $G, 150 G$, $300 G$ and $700 G$ respectively) or zein ( $100 Z, 150 Z, 300 Z$ and $700 Z$ respectively)

\begin{tabular}{|c|c|c|c|c|}
\hline Protein & Diet & $\begin{array}{c}\text { Crude protein } \dagger \\
(\mathrm{g} / \mathrm{kg})\end{array}$ & $\begin{array}{l}\text { Lipid } \\
(\mathrm{g} / \mathrm{kg})\end{array}$ & $\begin{array}{c}\text { Gross energy } \\
(\mathrm{MJ} / \mathrm{kg})\end{array}$ \\
\hline Casein & $\begin{array}{l}\mathrm{LF} / 100 \mathrm{C} \\
\mathrm{LF} / 150 \mathrm{C} \\
\mathrm{LF} / 300 \mathrm{C} \\
\mathrm{LF} / 700 \mathrm{C}\end{array}$ & $\begin{array}{r}93 \\
132 \\
265 \\
625\end{array}$ & $\begin{array}{l}21 \cdot 2 \\
20 \cdot 4 \\
22 \cdot 3 \\
25 \cdot 5\end{array}$ & $\begin{array}{l}17.6 \\
17 \cdot 8 \\
18.8 \\
21 \cdot 0\end{array}$ \\
\hline Gluten & $\begin{array}{l}\mathrm{LF} / 100 \mathrm{G} \\
\mathrm{LF} / 150 \mathrm{G} \\
\mathrm{LF} / 300 \mathrm{G} \\
\mathrm{LF} / 700 \mathrm{G}\end{array}$ & $\begin{array}{r}95 \\
134 \\
271 \\
625\end{array}$ & $\begin{array}{l}22 \cdot 0 \\
22 \cdot 2 \\
34 \cdot 1 \\
56 \cdot 2\end{array}$ & $\begin{array}{l}17 \cdot 2 \\
18.0 \\
19.0 \\
21.3\end{array}$ \\
\hline Zein & $\begin{array}{l}\mathrm{LF} / 100 \mathrm{Z} \\
\mathrm{LF} / 150 \mathrm{Z} \\
\mathrm{LF} / 300 \mathrm{Z} \\
\mathrm{LF} / 700 \mathrm{Z}\end{array}$ & $\begin{array}{r}91 \\
132 \\
265 \\
630\end{array}$ & $\begin{array}{l}20 \cdot 2 \\
24 \cdot 4 \\
28 \cdot 3 \\
30 \cdot 2\end{array}$ & $\begin{array}{l}17 \cdot 0 \\
17 \cdot 4 \\
18 \cdot 0 \\
20 \cdot 0\end{array}$ \\
\hline
\end{tabular}

$\dagger$ Nitrogen $\times 6 \cdot 25$.

$23 \mathrm{MJ} / \mathrm{kg}$ respectively. The value for lipid was based on determinations made on body lipid extracted from male animals given diets $40 \mathrm{C}, 150 \mathrm{C}$ and $500 \mathrm{C}$ (for details of these diets, see Table I, of Radcliffe \& Webster, 1976). The value for the heat combustion of body protein is that of Franke \& Weniger (1958). The correlation between total body energy estimated in this way for rats of both phenotypes and sexes fed on diets varying in casein content from 40 to $700 \mathrm{~g} / \mathrm{kg}$, and body energy determined directly (see Radcliffe \& Webster, I976, 1978) was good (r 0.99).

\section{RESULTS}

\section{Expt 1. Substitution of cellulose for sucrose}

The results for the apparent digestibility of the energy and $\mathrm{N}$ and for the metabolizability of the dietary energy of the four diets used in Expt $\mathrm{I}$ are given along with the results for the two corresponding cellulose-free diets used previously (see Radcliffe \& Webster, 1976, 1978) in Table 3. Since both sexes of both phenotypes digested dietary $N$ and energy and metabolized dietary energy with similar efficiency, the results have been pooled to give a single value for each diet. However, further details are available (Radcliffe, 1977).

Cellulose substitution reduced the apparent digestibility of dietary $N$, probably by increasing the loss of endogenous $\mathrm{N}$ into the gut. As expected the inclusion of cellulose lowered the digestibility of dietary energy. The decreases in metabolizability brought about by cellulose substitution were entirely due to increases in faecal energy losses.

Table 4 summarizes values obtained for the intake of food and metabolizable energy (ME) and for body composition at $66 \mathrm{~d}$ of age for the rats used in this experiment fed on diets having 150 or $300 \mathrm{~g}$ cellulose $/ \mathrm{kg}$. Figs. I and 2 illustrate how food intake, ME intake and body gains in this experiment compared with those for rats of both penotypes and sexes given diets containing $\mathrm{I} 50$ and $300 \mathrm{~g}$ casein $/ \mathrm{kg}$, but no cellulose (Radcliffe \& Webster, 1976 , I978).

The fatties had significantly $(P<0.001)$ greater ME intakes, body-weights and lipid contents than the corresponding sex-matched lean rats fed on the same diet. For the female rats, gains in body protein were the same for both phenotypes whatever the level of cellulose incorporation (see Table 4 and Fig. 2). For males the pattern was more complex (see Fig. 2). On cellulose-free diets, gains in body protein were significantly greater $(P<0.01)$ for the 

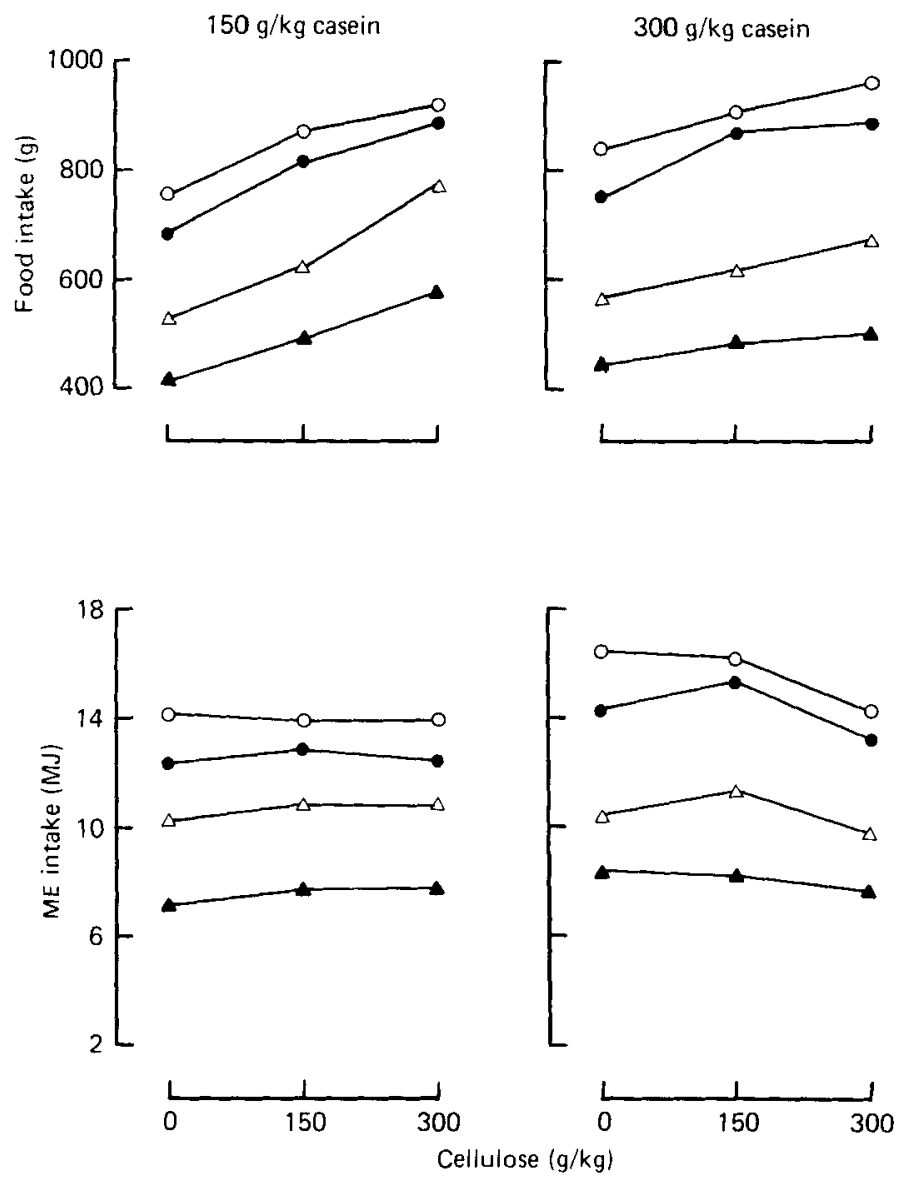

Fig. I. Total food intake (g) and metabolizable energy (ME) intake (MJ) during growth in fatty male $(O)$ and female $(\bullet)$, lean male $(\triangle)$ and female $(\Delta)$ rats offered to appetite, from 34 to $66 \mathrm{~d}$ of age, cellulose-free diets containing $150(a)$ or $300(b) \mathrm{g}$ casein $/ \mathrm{kg}$ (diets $150 \mathrm{C}$ and $300 \mathrm{C}$ respectively; for details, see Radcliffe \& Webster, 1976) and cellulose-containing diets having these levels of casein and 150 or $300 \mathrm{~g}$ cellulose $/ \mathrm{kg}$ (diets $150 \mathrm{C} / \mathrm{I} 50 \mathrm{CELL}, \mathrm{I} 50 \mathrm{C} / 300 \mathrm{CELL}, 300 \mathrm{C} / 150 \mathrm{CELL}, 300 \mathrm{C} / 300$ CELL respectively; for details, see Table I). The points for the rats fed on the cellulose-free diets are from Radcliffe \& Webster $(1976,1978)$. The remainder of the points refer to the animals used in Expt I (see p. I12).

Table 3. Expt I. Mean values for the apparent digestibility of the dietary energy and nitrogen and for the metabolizability of the dietary energy of diets containing 150 or $300 \mathrm{~g}$ casein $/ \mathrm{kg}$ (diets $\mathrm{I} 50$ and $300 \mathrm{C}$ respectively) and of diets having these levels of casein and $\mathrm{I} 50$ and $300 \mathrm{~g}$ cellulose $/ \mathrm{kg}$ (diets $150 \mathrm{C} / \mathrm{I} 50 \mathrm{CELL}, 150 \mathrm{C} / 300 \mathrm{CELL}$, and $300 \mathrm{C} / 300 \mathrm{CELL}$ respectively)

Digestibility

$\begin{array}{lccc}\text { Diet } \dagger & \mathrm{N} & \text { Energy } & \text { Metabolizability } \\ \text { I50 C } & 0.94 & 0.94 & 0.9 \mathrm{I} \\ \text { I50 C/150 CELL } & 0.91 & 0.83 & 0.8 \mathrm{I} \\ \text { I50 C/300 CELL } & 0.89 & 0.72 & 0.70 \\ 300 \mathrm{C} & 0.97 & 0.95 & 0.90 \\ 300 \mathrm{C} / 150 \mathrm{CELL} & 0.9 \mathrm{I} & 0.85 & 0.82 \\ 300 \mathrm{C} / 300 \mathrm{CELL} & 0.90 & 0.73 & 0.70\end{array}$

$\dagger$ For details, see Table I and Radcliffe \& Webster (1976). 


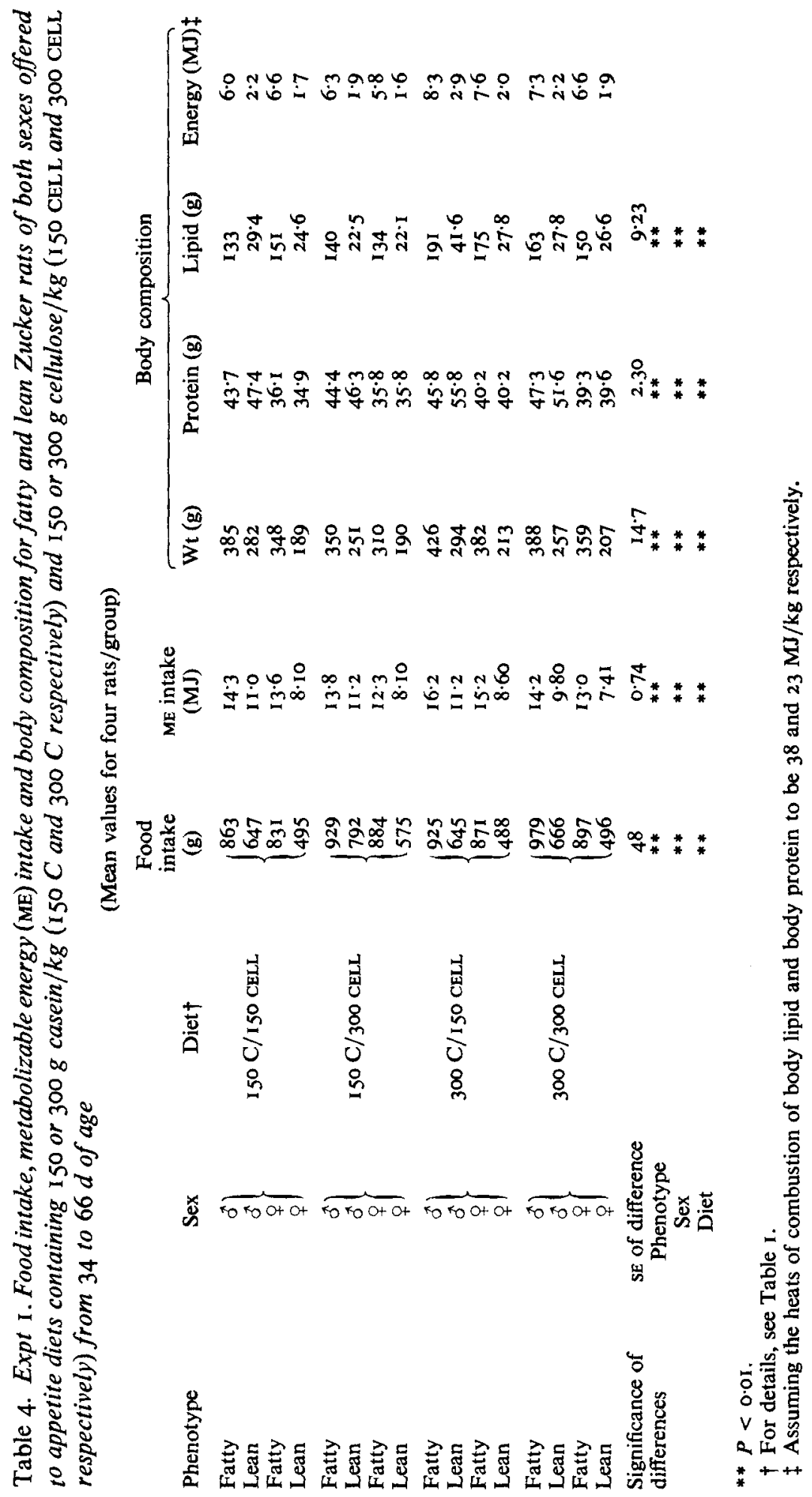



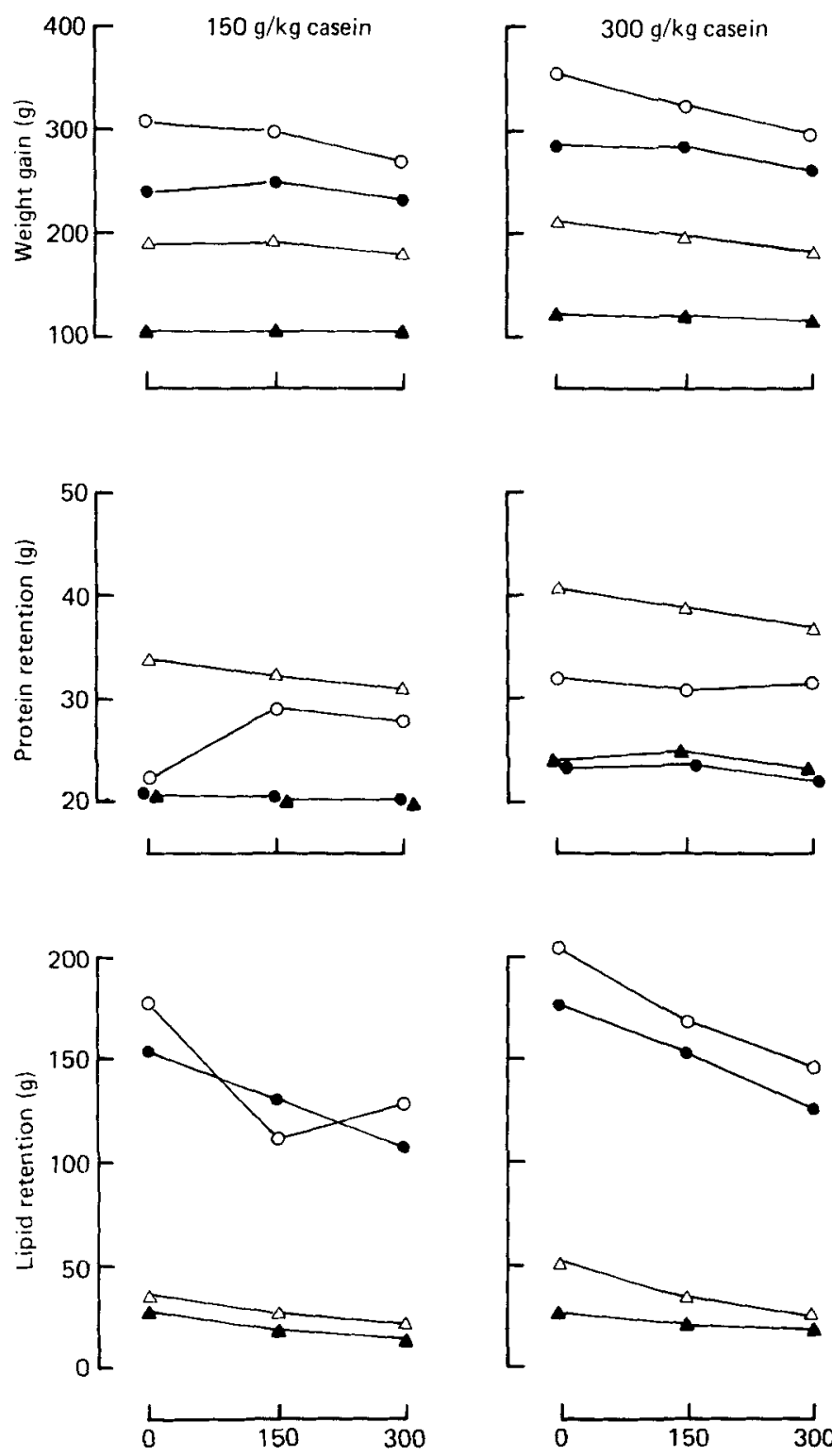

Cellulose $(\mathrm{g} / \mathrm{kg})$

Fig. 2. Changes in body composition during growth in fatty male $(\mathrm{O})$ and female ( $)$, lean male $(\triangle)$ and female $(\Delta)$ rats offered to appetite, from 34 to $66 \mathrm{~d}$ of age, cellulose-free diets containing I $50(a)$ or $300(b) \mathrm{g}$ casein $/ \mathrm{kg}$ (diets $\mathrm{I} 50 \mathrm{C}$ and $300 \mathrm{C}$ respectively) (for details, see Radcliffe \& Webster, I976) and cellulose-containing diets having these levels of casein and 150 or $300 \mathrm{~g}$ cellulose $/ \mathrm{kg}$ (diets $150 \mathrm{C} / \mathrm{I} 50 \mathrm{CELL}, 150 \mathrm{C} / 300 \mathrm{CELL}, 300 \mathrm{C} / 150 \mathrm{CELL}$ and $300 \mathrm{C} / 300 \mathrm{CELL}$ respectively) (for details, see Table I). The points for the rats fed on the cellulose-free diets are from Radcliffe $\&$ Webster $(1976,1978)$. The remainder of the points refer to the animals used in Expt I (see p. 112).

lean males than for the fatties, but as the content of cellulose in the diet was increased, this difference diminished so that at $300 \mathrm{~g}$ cellulose $/ \mathrm{kg}$ the difference between the phenotypes was no longer statistically significant. As expected, males ate more than females and this difference was greater for the lean rats than for the fatties (see Radcliffe \& Webster, 1978). 
Table 5. Expt 2. Mean values for the apparent digestibility of the dietary energy and nitrogen and for the metabolizability of the dietary energy of low-fat $(L F)$ diets containing $100,150,300$ and $700 \mathrm{~g}$ casein $/ \mathrm{kg}(100 \mathrm{C}, \mathrm{I} 50 \mathrm{C}, 300 \mathrm{C}$ and $700 \mathrm{C}$ respectively) and the corresponding isonitrogenous diets containing gluten (100 $G, I 50 G, 300 G$ and $700 \mathrm{G}$ respectively) and zein ( $100 Z$, I $50 Z, 300 Z$ and $700 Z$ respectively.)

\begin{tabular}{|c|c|c|c|c|}
\hline \multirow[b]{2}{*}{ Protein } & \multirow[b]{2}{*}{ Diet $†$} & \multicolumn{2}{|c|}{ Digestibility } & \multirow[b]{2}{*}{ Metabolizability } \\
\hline & & $N$ & Energy & \\
\hline Casein & $\begin{array}{l}\mathrm{LF} / 100 \mathrm{C} \\
\mathrm{LF} / 150 \mathrm{C} \\
\mathrm{LF} / 300 \mathrm{C} \\
\mathrm{LF} / 700 \mathrm{C}\end{array}$ & $\begin{array}{l}0.97 \\
0.97 \\
0.97 \\
0.98\end{array}$ & $\begin{array}{l}0.97 \\
0.97 \\
0.97 \\
0.98\end{array}$ & $\begin{array}{l}0.92 \\
0.93 \\
0.93 \\
0.88\end{array}$ \\
\hline Gluten & $\begin{array}{l}\mathrm{LF} / 100 \mathrm{G} \\
\mathrm{LF} / 150 \mathrm{G} \\
\mathrm{LF} / 300 \mathrm{G} \\
\mathrm{LF} / 700 \mathrm{G}\end{array}$ & $\begin{array}{l}0.92 \\
0.93 \\
0.95 \\
0.96\end{array}$ & $\begin{array}{l}0.97 \\
0.97 \\
0.97 \\
0.97\end{array}$ & $\begin{array}{l}0.94 \\
0.95 \\
0.93 \\
0.86\end{array}$ \\
\hline Zein & $\begin{array}{l}\mathrm{LF} / 100 \mathrm{Z} \\
\mathrm{LF} / \mathrm{I} 5 \mathrm{Z} \\
\mathrm{LF} / 300 \mathrm{Z} \\
\mathrm{LF} / 700 \mathrm{Z}\end{array}$ & $\begin{array}{l}0.83 \\
0.87 \\
0.84 \\
0.82\end{array}$ & $\begin{array}{l}0.94 \\
0.95 \\
0.94 \\
0.83\end{array}$ & $\begin{array}{c}0.91 \\
0.88 \\
0.86 \\
-\end{array}$ \\
\hline
\end{tabular}

Within each sex and phenotype, increasing the cellulose content always increased total food intake. This effect was smaller at the higher casein level. At the lower casein level this increase in food intake was such as to maintain ME intake constant for all concentrations of cellulose. At $300 \mathrm{~g}$ casein $/ \mathrm{kg}$, ME intake was lower at the higher cellulose level than at the lower one, but this difference was significant $(P<0.05)$ for the fatties only.

The effect of increasing cellulose was to reduce body lipid content (Fig. 2) even though at the lower casein level ME intake was unchanged. In other words, the presence of apparently undigested cellulose in the food increased the heat production of these rats.

\section{Expt 2. Substitution of gluten or zein for casein}

The results for the apparent digestibility of the energy and $\mathrm{N}$ and the metabolizability of the dietary energy of the twelve diets used in Expt 2 are given in Table 5. Since differences between phenotypes in the digestibility of dietary energy and $\mathrm{N}$ and in metabolizability were small, the results for both phenotypes have been pooled to give a single value for each diet. However, further details are available (Radcliffe, 1977). The spillage of food into the urine of the rats fed on diet $\mathrm{LF} / 700 \mathrm{Z}$ took place to such an extent as to render pointless an analysis of the urine and it was not possible, therefore, to calculate the metabolizability for this diet for either phenotype. We have reported earlier how Zucker rats appeared to search through unbalanced diets as if for specific nutrients (Radcliffe \& Webster, 1976). This appeared to be an extreme example of this behaviour. Lower values for the apparent digestibility of energy and $\mathrm{N}$ and metabolizability were obtained for the animals fed on zein than for those fed on the casein and gluten diets. This may have been due to a relatively greater contribution of endogenous faecal $\mathrm{N}$ and energy and endogenous urinary energy to the respective totals for the animals fed on zein.

Table 6 presents values for the intake of digestible energy (DE) and ME, and for body composition at $66 \mathrm{~d}$ of age for rats in this experiment given low-fat diets containing casein, gluten or zein as the only source of protein. Fig. 3 illustrates the effects of protein quality on DE intake and gains in body-weight, protein and lipid.

At dietary protein levels of about $300 \mathrm{~g} / \mathrm{kg}$ or above, DE intake, body-weight gain and 

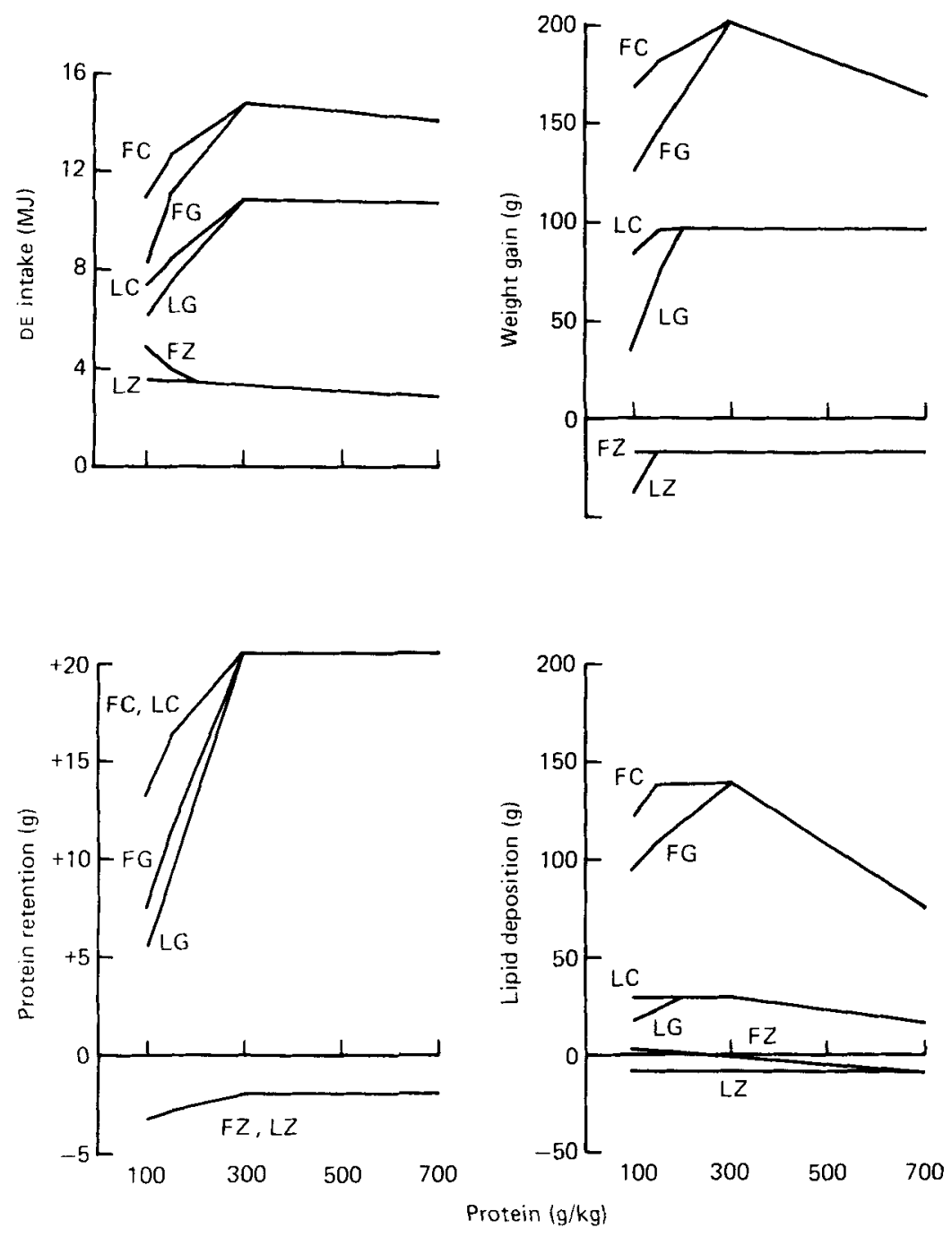

Fig. 3. Digestible energy (DE) intake (MJ) and changes in body composition during growth in fatty (F) and lean (L) female rats offered to appetite diets having various amounts of casein (C), gluten $(G)$ and zein ( $Z$ ) (for details, see Table 2). The letters FG refer, for example, to fatty rats given diets containing gluten.

lipid deposition were the same for diets containing gluten or casein for rats of the same phenotype. In these female rats, protein deposition was, as before, the same for both phenotypes. The effect of reducing dietary protein content below about $300 \mathrm{~g} / \mathrm{kg}$ was to reduce $\mathrm{DE}$ intake and body gains and this effect was greater for gluten than for casein. In general it was similar for lean and fatty rats, although fatties appear to have retained slightly, but not significantly, more protein on low-gluten diets than the lean rats.

Zein, which has little or no tryptophan, failed to support growth in either phenotype (Fig. 3). At the lowest concentration of zein, fatties ate more than lean rats, but at zein concentrations of from 300 to $700 \mathrm{~g} / \mathrm{kg}$ both phenotypes ate the same amount of DE. However, the intake of digestible $\mathrm{N}$ over the whole range of dietary zein concentrations increased by $290 \%$ for the fatties and $380 \%$ for the leans. 


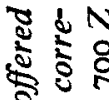

논

ปั

총 을

突 $N$

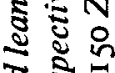

है

웡응

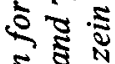

ป

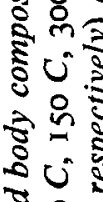

รี 80

$\underbrace{}_{\infty} 8$

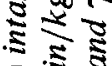

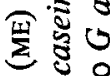

के

ะัะ

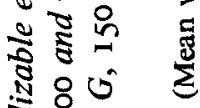

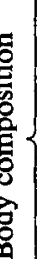

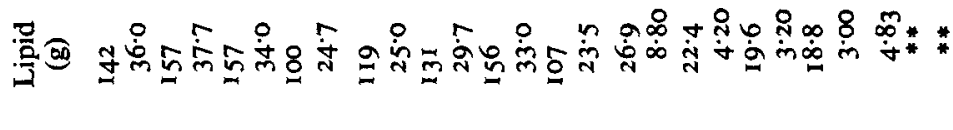

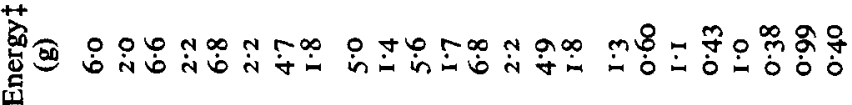

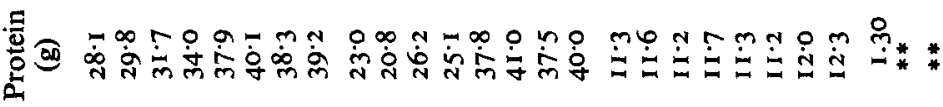

产

舟

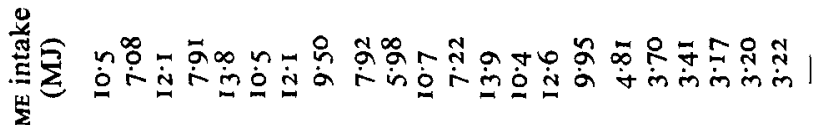

递㱏

㝏

UUUUUUUU 00000000 NNNNNNNN

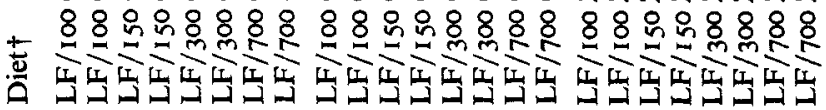

넴.

ข 1

응

को $\frac{1}{5}$

( $)$

$\frac{2}{2}: \frac{2}{0}$

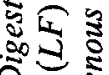

ㄱ 5

卷

出皮

$6: \stackrel{2}{\circ}$

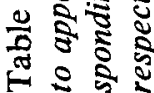

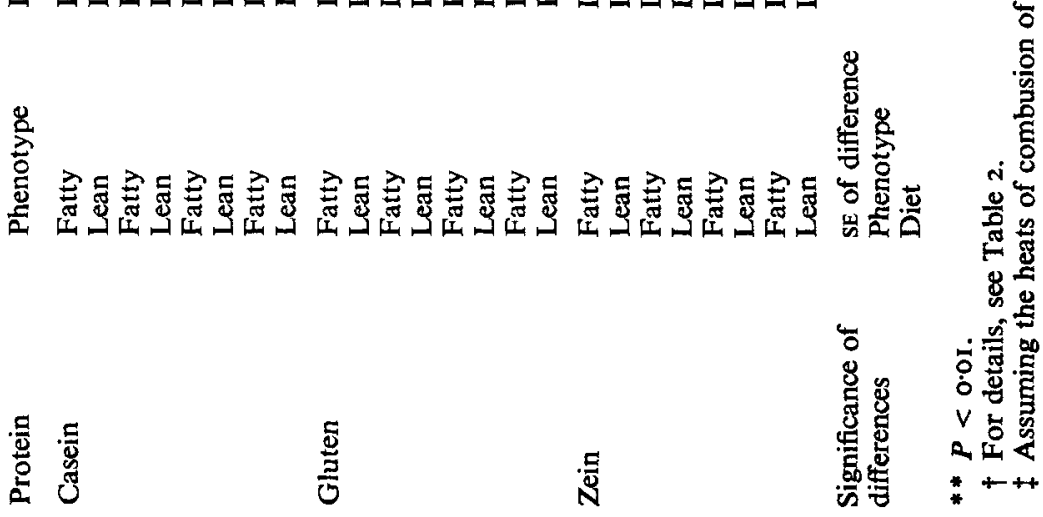



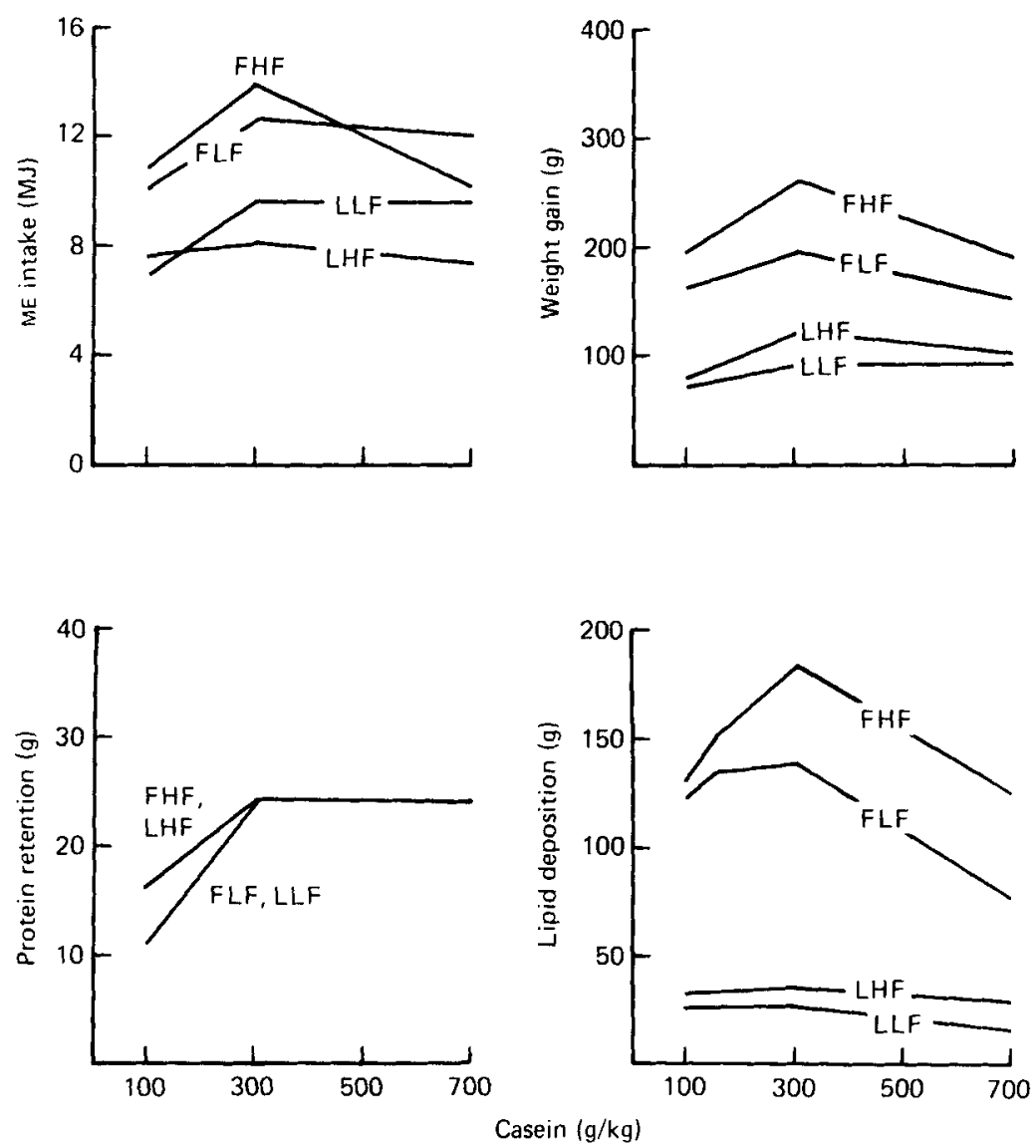

Fig. 4. Total metabolizable energy (ME) intake (MJ) and changes in body composition during growth from 34 to 66 days of age for fatty (F) and lean (L) female rats from Expt 2 offered to appetite the low-fat (LF) diets having $20 \mathrm{~g}$ lipid $/ \mathrm{kg}$ and $100,150,300$ or $700 \mathrm{~g}$ casein $/ \mathrm{kg}$ (diets $\mathrm{LF} / 100 \mathrm{C}, \mathrm{LF} / 150 \mathrm{C}, \mathrm{LF} / 300 \mathrm{C}$ and $\mathrm{LF} / 700 \mathrm{C}$ respectively) (for details, see Table 1 ) and for the corresponding female rats offered to appetite high-fat (HF) diets having $200 \mathrm{~g}$ lipid $/ \mathrm{kg}$ and the same levels of casein (diets $100 \mathrm{C}, 150 \mathrm{C}, 300 \mathrm{C}$ and $700 \mathrm{C}$ respectively) (for details, see Radcliffe \& Webster, 1976). The letters FHF refer, for example, to fatty rats given a high-fat diet.

Figure 4 compares results for female rats fed on the LF ( $20 \mathrm{~g}$ lipid $/ \mathrm{kg}$ ) diets containing casein with those given high-fat diets having $200 \mathrm{~g}$ lipid $/ \mathrm{kg}$ (Radcliffe \& Webster, 1976). ME intake was higher for fatties than for the lean rats. Variation of protein content for any one phenotype at any level of fat presented a quite clear curvilinear response.

The rate of lipid deposition was higher for the fatties at all protein levels and higher on the high-fat diets than on the low-fat diets for both phenotypes. The rate of protein deposition was the same for both phenotypes at all dietary levels of protein at both lipid levels, but it was slightly lower at the lower level of lipid over a range of from 100 to $300 \mathrm{~g}$ casein $/ \mathrm{kg}$. At higher casein levels the rate of protein deposition was similar and maximal for both phenotypes at both lipid levels. 


\section{DISCUSSION}

\section{Animals achieving the maximal rate of protein deposition}

These results continue to favour the hypothesis that both lean and fatty Zucker rats regulate food intake during growth so as to sustain a maximal rate of protein deposition, provided that the diet contains protein in sufficient quantity and of sufficient quality; in other words a sufficiency of all essential amino acids.

The rate of protein deposition achieved by the rats fed on diets containing 150 or $300 \mathrm{~g}$ cellulose $/ \mathrm{kg}$ and $300 \mathrm{~g}$ casein $/ \mathrm{kg}$ was, with one exception (the lean males) equal to the maximal rate achieved by similar rats fed on cellulose-free diets containing 300 to $700 \mathrm{~g}$ casein/kg (Radcliffe \& Webster, 1976, 1978). Inclusion of cellulose in these diets did however reduce weight gain and lipid deposition. ME intakes were similar to, or slightly lower than, those of rats given cellulose-free diets (Figs. I and 2) which means that, in all instances, substitution of cellulose for sucrose increased metabolic heat production.

Rats given diets containing casein or gluten at 300 or $700 \mathrm{~g} / \mathrm{kg}$ had maximal rates of protein deposition but weight gain and lipid deposition both decreased with increasing protein content. DE intake was unchanged for the lean rats but decreased for the fatties. Reducing the lipid content of diets containing casein also reduced weight gain and lipid deposition but protein deposition was still regulated at the same maximal level. All these observations reinforce our other original conclusion that body lipid content or lipid deposition rate are of little or no consequence in the regulation of food intake in the growing rat. Krahl (1976) surgically removed $26 \%$ of body fat from adult Sprague-Dawley rats. These animals did not increase food intake to make good this absolute reduction in body fat although they might have been expected to have done so if, as Kennedy (1953) has suggested, the adult rat regulates food intake to keep its body lipid stores constant. Taken together, these observations suggest that body lipid content has little effect on food intake in the growing rat or in the adult.

\section{Animals having submaximal rates of protein deposition}

As cellulose was substituted for sucrose in diets that did not promote maximal protein deposition (150 C), the rats ate more gross energy and digestible $\mathrm{N}$, but kept their intake of ME almost constant (Fig. I). Substitution of cellulose for sucrose had little or no effect on the rate of protein deposition except for the fatty male rats, for whom protein deposition did increase, although not quite to the maximal level observed on diets adequate in protein. Thus the increased intake of digestible $\mathrm{N}$ was used less efficiently to promote protein deposition. Moreover, since increasing cellulose reduced the rate of lipid deposition, a greater proportion of ME must again have been lost as heat.

These observations do not entirely accord with those of Meyer (1958). Like Meyer's (1958) rats, rats in the present study ate more digestible $\mathrm{N}$ when cellulose was substituted for sucrose in a low-protein diet but, unlike Meyer's (1958), those in the present study (with the exception of the fatty males) did not grow faster. Nevertheless it is still possible that the intake of our rats was limited by an inability to dispose of a relative excess of ME as heat and lipid since, within each phenotype, the total amount of ME going to heat and lipid was about the same for the $\mathrm{I} 50 \mathrm{C}$ diets at 0,150 or $300 \mathrm{~g}$ cellulose $/ \mathrm{kg}$. The rate of lipid deposition on lowprotein diets obviously differed between the phenotypes and was also affected by the lipid content of the diet (Fig. 4) being greater when a greater proportion of ME was provided as lipid. These observations suggest that lipid deposition per se has little effect on food intake even on low-protein diets. At this stage we can only conclude, in general terms, that Zucker rats regulate their intake of $\mathrm{ME}$, rather than digestible protein, to meet their energy requirement for the limited amount of work possible in these circumstances; work being taken to 
Table 7. Expt 2. Intake of digestible energy (DE) $\dagger$ and nitrogen, and the efficiency of utilization of digestible $N$ in fatty and lean female rats offered to appetite diets $L F / 100 C, L F / 100 G$, $L F / 100 Z$ and $L F / 700 Z$

$\begin{array}{lllccc}\text { Phenotype } & \text { Diet } & \text { Protein } & \begin{array}{c}\text { DE intake } \\ \text { (MJ) }\end{array} & \begin{array}{c}\text { Intake of } \\ \text { digestible N (g) }\end{array} & \begin{array}{c}\text { N retention/ } \\ \text { intake of digestible N }\end{array} \\ & \text { LF/100 C } & \text { Casein } & 10.9 & 8.7 & 0.24 \\ & \text { LF/100 G } & \text { Gluten } & 8.20 & 6.9 & 0.18 \\ & \text { LF/100 Z } & \text { Zein } & 4.95 & 3.7 & -0.14 \\ \text { Lean } & \text { LF/700 Z } & \text { Zein } & 2.98 & 14.6 & -0.02 \\ & \text { LF/100 C } & \text { Casein } & 7.50 & 6.0 & 0.38 \\ & \text { LF/100 G } & \text { Gluten } & 6.10 & 5.2 & -0.22 \\ & \text { LF/100 Z } & \text { Zein } & \mathbf{3 . 7 7} & 2.8 & -0.02\end{array}$

$\dagger$ Values given for $D E$ rather than $M E$ because the latter could not be measured for diet LF/700 $Z$.

$\ddagger$ For details, see Table 2.

include the energy costs associated with protein and fat deposition during growth (see Pullar \& Webster, 1977).

The present results are also not entirely compatible with the hypothesis that plasma amino acid patterns regulate food intake; the aminostat theory of Almquist (1954) and Mellinkoff (1957). Harper et al. (1970) suggested that rats given diets limited or unbalanced with respect to amino acids restrict food intake in order to preserve amino acid homoeostasis. In the present experiments, rats getting restricted amounts of protein as gluten ate less than those getting an isonitrogenous amount of protein as casein (Table 7). If this had simply been due to a low plasma level of the limiting amino acids then one would have expected the rats to eat more. This observation fits the aminostat hypothesis (Almquist, 1954; Mellinkoff, 1957) since at the low rate of growth induced by deficiencies in limiting amino acids, other nonlimiting amino acids would tend to accumulate and this may have induced satiety (Leung \& Rogers, I969; Sanahuja \& Harper, 1973). Thus intakes containing I00 g protein $/ \mathrm{kg}$ decreased as the efficiency of utilization of dietary $N$ decreased (Table 7 ). Tables 6 and 7 and Fig. 3 also showed however that rats ate rather similar amounts of DE on all zein diets which promoted no net protein deposition, despite high differences in intake of digestible $\mathrm{N}$. In this instance, therefore, both fat and lean rats ate to sustain their energy requirements for maintenance irrespective of the amount of amino acids that they were absorbing but failing to use for growth. While in the instance of reduced growth (e.g. diet LF/100 G) an aminostatic mechanism may have induced satiety, in the extreme situation of no growth, such a mechanism must have been over-ridden by the need to take in enough ME for maintenance.

Both the hypothesis of Meyer (1958) and the aminostat hypothesis imply that intake of low-protein diets is restricted by the need to preserve homoeostasis. It is equally possible that rats could have eaten more without a serious disturbance to homoeostasis but elected not to because to have done so would not have improved their rate of protein deposition or even reduced it. This could occur if any increase in protein consumption was entirely used up in the metabolism of the associated increase in non-protein energy, or, more specifically, if all the increment in the first limiting amino acid was used up in the catabolism of surplus non-limiting amino acids.

The present results do not therefore point to any single factor as being responsible for limiting food intake in rats given diets that do not support maximal growth rate. Indeed, in view of the multiplicity of factors that have been implicated in the control of appetite, it would have been surprising if they had. Nevertheless, the present study, taken together with earlier work (Radcliffe \& Webster, 1976, 1978) does permit certain firm conclusions and 
exclusions as to the control of food intake in the Zucker rat. These are: (I) food intake is precisely regulated in both lean and fatty Zucker rats. If the diet permits, both phenotypes will eat to sustain, during growth, their maximal rate of protein deposition. This rate is the same for females of both phenotypes, higher for fatty males and highest for lean males; (2) rates of lipid deposition and weight gain are of little or no direct importance in the regulation of food intake. This reinforces the conclusion that hyperphagia in the fatty rat is a normal response directed towards the maintenance of energy and protein homoeostasis when faced with a congenital error of metabolism leading to an abnormally high propensity for lipid deposition; (3) rats given diets that fail to support maximal rates of protein deposition appear to regulate their food intake to supply the ME required for the limited amount of growth that is possible. They do not increase food intake in order simultaneously to acquire more protein and so grow faster, though whether this is due to an inability to dissipate excess energy, satiety induced by unused amino acids, a recognition that increased intake would not enhance growth, or any combination of these factors is not yet clear. It appears, however, that for diets absolutely or relatively deficient in amino acids, it is energy intake that is regulated rather than the gross intake of dietary protein, or of specific limiting amino acids.

The authors gratefully acknowledge the support of the British Nutrition Foundation.

\section{REFERENCES}

Almquist, H. J. (1954). Archs Biochem. Biophys. 52, 197.

Atkinsen, T., Fowler, V. R., Garton, G. A. \& Lough, A. K. (1972). Analyst, Lond. 97, 562.

Davidson, J., Mathieson, J. \& Boyne, A. W. (1970). Analyst, Lond. 95, I8I.

Franke, E. R. \& Weniger, J. H. (1958). Arch. Tierernähr. 8, 8I.

Harper, A. E., Benevenga, N. J. \& Wohlheuter, R. M. (1970). Physiol. Rev. 50, 420.

Kennedy, G. C. (1953) Proc. Roy. Soc., Lond. I40B, 578.

Krahl, J. G. (1976). Am. J. Physiol. 231, 1090.

Leung, P. M-B. \& Rogers, Q. R. (I969). Life Sci. 8, 2, I.

Mellinkoff, S. M. (1957). A. Rev. Physiol. 19, 193.

Meyer, J. H. (1958). Am. J. Physiol. 193, 488.

Meyer, J. H. \& Hargus, W. A. (1959). Am. J. Physiol. 197, 1350.

Pullar, J. D. \& Webster, A. J. F. (I977), Br. J. Nutr. 37, 355.

Radcliffe, J. D. (1977). The regulation of food intake during growth in obese (fatty) and lean rats of the Zucker strain. PhD Thesis, University of Aberdeen.

Radcliffe, J. D. \& Webster, A. J. F. (1976). Br. J. Nutr. 36, 457.

Radcliffe, J. D. \& Webster, A. J. F. (I978). Br. J. Nutr. 39, 483 .

Sanahuja, J. C. \& Harper, A. E. (1973). Am. J. Physiol. 204, 686.

Zucker, L. M. \& Zucker, T. R. (I96I). J. Hered. 52, 275. 